\title{
Складнощі організації доопераційного періоду при лікуванні паціентів з ускладненими формами жовчнокам'яної хвороби з супутнім цирозом печінки
}

\begin{abstract}
Мета роботи: встановлення основних чинників складності організації доопераційного періоду та діагностики цирозу печінки безпосередньо перед проведенням оперативного втручання.

Матеріали і методи. Ретроспективно були проаналізовані 77 історій хвороб пацієнтів. Критеріями відбору для даного дослідження були наявність ускладнених форм ЖКХ (гострий калькульозний холецистит, холедохолітіаз з обтураційною жовтяницею та синдром Міріззі) та наявність цирозу печінки. Залежно від строку діагностики цирозу печінки всі пацієнти були умовно розподілені на 2 групи; група 1 - пацієнти з діагностованим цирозом печінки на доопераційному етапі (62 хворі) та група 2 - хворі, діагноз цирозу в котрих встановлений інтраопераційно (15 хворі). Всі пацієнти на передопераційному етапі були обстежені згідно з протоколами діагностики та лікування пацієнтів з ускладненими формами ЖКХ. Стадію цирозу оцінювали за системою Child-Turcotte-Pugh та згідно зі шкалою MELD. Серед супутньої патології превалювали хронічна ішемічна хвороба серця (група 1 - 41 та група 2 - 4 випадки), гіпертонічна хвороба (група 1 - 15 хворих, група 2 - 2), цукровий діабет (група 1 - 1 випадок, група 2 - 3 ), ожиріння (група 1 - 2 випадки, група 2 - 4).

Результати досліджень та їх обговорення. За результатами дослідження в групі 2 спостерігали більший відсоток післяопераційних ускладнень, що безпосередньо пов’язано з інтраопераційною діагностикою цирозу печінки та відсутністю ретельної оцінки ризиків виконання операції. Діагностика цирозу печінки на передопераційному етапі в багатьох випадках дозволяє більш адекватно оцінювати ризики проведення оперативних втручань, а заздалегідь призначена відповідна терапія значно знижує ризик виникнення післяопераційних ускладнень. Найбільш “небезпечними” з точки зору недіагностування цирозу печінки на доопераційному етапі є поєднання цирозу печінки 3 ожирінням, цукровим діабетом та наявність післяопераційних злук у черевній порожнині. В передопераційному періоді слід більше уваги приділяти неінвазивним методам діагностики, які можуть допомогти запідозрити цироз печінки, навіть при відсутності даних за портальну гіпертензію; серед них це індекс deRitis та FibroTest.
\end{abstract}

Ключові слова: жовчнокам’яна хвороба; цироз печінки.

Постановка проблеми і аналіз останніх досліджень та публікацій. За останні роки у світі поряд зі зростаючою захворюваністю на жовчнокам’яну хворобу стрімко зростає і захворюваність на цироз печінки. Незважаючи на розвиток малоінвазивних технологій та інструментального оснащення медичних закладів, яке значно зменшило ризик виникнення періопераційних ускладнень в лікуванні ускладнених форм ЖКХ, цироз печінки в багатьох випадках залишається одним з найважчих та найнезручніших станів у таких пацієнтів. Раніше ми вже зупинялися на основних причинах незадовільних результатів лапароскопічної холецистектомії у пацієнтів з цирозом печінки [1]. Але в ході подальших досліджень виявилось, що цироз печінки (особливо в ранніх стадіях) часто “маскується" і його не завжди можна вчасно виявити. На сьогодні доведено, що цироз печінки сприяє літогенезу в жовчному міхуpi, завдяки зниженню моторики, жовчного міхура. Негативні прояви цирозу печінки практично в усіх системах організму людини, таких, як системи травлення, кардіо-васкулярній, дихальній та системі гемостазу значно підвищують ризики ви- никнення ускладнень під час буд-яких операцій на тлі цирозу печінки $[2,3,4]$. Лікування пацієнтів з ускладненими формами ЖКХ на тлі верифікованого цирозу печінки $є$ дуже вибагливим та ризикованим через необхідність дуже ретельної оцінки ризиків обраної тактики лікування. Стандартний діагностичний алгоритм ускладнених форм жовчнокам'яної хвороби дозволяє діагностувати цироз печінки лише при декомпенсованій стадії цирозу печінки, а в багатьох випадках діагноз цирозу печінки встановлюється інтраопераційно, що ставить хірурга в досить складне становище та змушує приймати рішення відносно тактики подальшого лікування інтраопераційно [5].

Мета роботи: висвітлення основних чинників складності організації діагностично-лікувального процесу пацієнтів з ускладненими формами ЖКХ на тлі цирозу печінки у передопераційному періоді та виявлення впливу до операційної діагностики цирозу печінки на перебіг і результат лікування пацієнтів з ускладненими формами ЖКХ.

Матеріали і методи. У роботі проаналізовано 77 історій хвороб пацієнтів. Критеріями вклю- 
чення пацієнтів у дослідження були наявність укладнених форм ЖКХ: гострий калькульозний холецистит, синдром Міріззі та холедохолітіаз 3 обтураційною жовтяницею та наявність цирозу печінки. Залежно від верифікації цирозу всі пацієнти були умовно розділені на 2 групи. В першу групу увійшли 62 пацієнти $(80,5$ \%) зі встановленим діагнозом цироз печінки на доопераційному етапі, а в другу групу - 15 пацієнтів (19,5 \%), у яких цироз був підтверджений інтраопераційно. Розподіл пацієнтів за нозологіями мав наступний характер: гострий калькульозний холецистит - 68 пацієнтів (група $1-55$, група 2 - 13), холедохолітіаз - 7 (група $1-6$, група $2-1$ ), синдром Міріззі - 2 пацієнти (табл. 1).

Діагностичний процес в обох групах розпочинався ідентично зі стандартних лабораторноінструментальних досліджень. Всім пацієнтам проводилось ультразвукове дослідження черевної порожнини з обов'язковою оцінкою портальної гіпертензії та еластографією. Езофагогастродуоденоскопія проводилась 3 обов'язковим стадіюванням варикозно-розширених вен шлунково-кишкового тракту. Визначення стадії цирозу здійснювалась за системами Child-TurcottePugh та MELD (ModelofEndstageLiverDisease). В усіх випадках на момент госпіталізації та безпосередньо перед хірургічним втручанням стан пацієнта оцінювали за шкалою АРАСНЕ ІІ. При підозрі на холедохолітіаз усім пацієнтам проводилась МРТ-холангіопанкреатографія та мультиспіральна комп’ютерна томографія. Проведення ендоскопічної ретроградної холангіопанкреатографії з діагностичною метою проводилось тільки в рідкісних ситуаціях.
Розподіл хворих 1 та 2 групи згідно зі стадією цирозу представлено в таблиці 2. ChildA спостерігали у 41 пацієнта (група 1 - 35 хворих, група $2-$ 6 хворих), ChildB - 34 випадки (група 1-26, група 2-8), ChildC - 2 - по одному в першій та другій групах.

В усіх випадках проводилось консультування пацієнтів суміжними спеціалістами. У більшості пацієнтів була виявлена супутня патологія. Перелік цих захворювань представлено в таблиці 3.

За даними таблиці 3, серед них частіше зустрічались хронічна ішемічна хвороба серця (у 45 випадках), гіпертонічна хвороба (17 випадків). Ожиріння спостерігалось у 6 пацієнтів, з індексом маси тіла більше 38 кг/ $\mathrm{M}^{2}$ - 2 випадки у 2 групі пацієнтів.

Результати досліджень та їх обговорення. Лікування пацієнтів на доопераційному етапі в обох групах мали в більшості схожий характер. Дезінтоксикаційний, антибактеріальний компоненти були присутні в обох групах. У групі 3 верифікованим цирозом печінки лікування обов'язково доповнювалось гепатопротекторним та, при необхідності, нутритивним компонентом. Після проведеної консервативної терапії у 2 пацієнтів першої групи з ознаками гострого калькульозного холециститу наступив регрес клініки та пацієнтів виписали на амбулаторне лікування. Спектр оперативнихвтручань у пацієнтів 1 та 2 групи представлено в таблиці 4.

У групі 2 у 1 пацієнта $з$ тяжким цукровим діабетом, хронічною хворобою нирок та загостренням хронічного пієлонефриту був запідозрений гострий деструктивний холецистит за даними УЗД. Пацієнту в ургентному порядку було вико-

Таблиця 1. Розподіл пацієнтів за нозологіями

\begin{tabular}{|c|c|c|}
\hline \multirow{2}{*}{ Основний діагноз } & \multicolumn{2}{|c|}{ Кількість пацієнтів, n } \\
\hline & група 1 & група 2 \\
\hline Гострий калькульозний холецистит & 55 & 13 \\
\hline Холедохолітіаз & 6 & 1 \\
\hline Синдром Міріззі & 1 & 1 \\
\hline
\end{tabular}

Таблиця 2. Розподіл пацієнтів груп згідно зі стадією цирозу печінки

\begin{tabular}{|l|c|c||}
\hline \multirow{2}{*}{\multicolumn{1}{|c|}{ Стадія цирозу печінки за Child-Turcotte-Pugh }} & група 1 & група 2 \\
\cline { 2 - 3 } & 35 & 6 \\
\hline ChildA & 26 & 8 \\
\hline ChildB & 1 & 1 \\
\hline ChildC & 1 & $\mathrm{n}$ \\
\hline \hline
\end{tabular}


Таблиця 3. Супутні захворювання у хворих

\begin{tabular}{|c|c|c|}
\hline \multirow{2}{*}{ Супутнє захворювання } & \multicolumn{2}{|c|}{ Кількість пацієнтів, n } \\
\hline & група 1 & група 2 \\
\hline Гіпертонічна хвороба & 15 & 2 \\
\hline Хронічна ішемічна хвороба серця & 41 & 4 \\
\hline Цукровий діабет, тип 2 & 1 & 3 \\
\hline Ожиріння & 2 & 4 \\
\hline Виразкова хвороба шлунка та дванадцятипалої кишки & 1 & 1 \\
\hline Ревматоїдний поліартрит & - & 1 \\
\hline Хронічна хвороба нирок, хронічний пієлонефрит & - & 1 \\
\hline Злуковий процес черевної порожнини & 1 & 1 \\
\hline
\end{tabular}

Таблиця 4. Спектр оперативних втручань

\begin{tabular}{|c|c|c|}
\hline \multirow{2}{*}{ Тип оперативного вручання } & \multicolumn{2}{|c|}{ Кількість пацієнтів, n } \\
\hline & група 1 & група 2 \\
\hline ЛсХЕ & 52 & 11 \\
\hline Конверсійна холецистектомія & 2 & 1 \\
\hline $\begin{array}{l}\text { Лапаротомія, холецистектомія, холедохолітоекстракція, } \\
\text { холедохоскопія, зовнішне дренування холедоха }\end{array}$ & 2 & - \\
\hline ЕПСТ+літоекстракція, ЛсХЕ & 3 & 1 \\
\hline Холецистостомія під УЗ-контролем & 1 & \\
\hline $\begin{array}{l}\text { Лапаротомія холецистектомія, ушивання холецистохоледо- } \\
\text { хеальної нориці на зовнішньому каркасному дренажі }\end{array}$ & - & 1 \\
\hline $\begin{array}{l}\text { Лапароскопічна холецистектомія, ушивання холецистохоледо- } \\
\text { хеальної нориці на зовнішньому каркасному дренажі }\end{array}$ & 1 & - \\
\hline Діагностична лапароскопія & - & 1 \\
\hline
\end{tabular}

нано оперативне втручання: діагностична лапароскопія, під час якого встановлено діагноз цирозу печінки, який на доопераційному етапі не був виявлений навіть завдяки сучасним методам діагностики. На жаль, в післяопераційному періо- ді наступила смерть внаслідок декомпенсації цирозу, розвинулась тяжка печінкова енцефалопатія та набряк головного мозку. В післяопераційному періоді спостерігались такі ускладнення, які представлені в таблиці 5.

Таблиця 5. Ускладнення в післяопераційному періоді

\begin{tabular}{|c|c|c|}
\hline \multirow{2}{*}{ Тип післяопераційного ускладнення } & \multicolumn{2}{|c|}{ Кількість пацієнтів, n } \\
\hline & група 1 & група 2 \\
\hline Післяопераційна кровотеча (ложе жовчного міхура) & 1 & 3 \\
\hline Післяопераційна холерея & 1 & - \\
\hline Формування абсцесу печінки та підпечінкового простору & 1 & - \\
\hline Нагноєння рани & 3 & 4 \\
\hline Печінково-ниркова недостатність & - & 1 \\
\hline
\end{tabular}




\section{З ДОСВІДУ РОБОТИ}

Висновки. 1. Діагностика цирозу печінки на передопераційному етапі в багатьох випадках дозволяє більш адекватно оцінювати ризики проведення оперативних втручань, а заздалегідь призначена відповідна терапія значно знижує ризик виникнення післяопераційних ускладнень.

Найбільш “небезпечними” з точки зору недіагностування цирозу печінки на доопераційному етапі $є$ поєднання цирозу печінки з ожирінням, цукровим діабетом та наявність післяопераційних злук у черевній порожнині.

У передопераційному періоді слід більше уваги приділяти неінвазивним методам діагностики, які можуть допомогти запідозрити цироз печінки навіть при відсутності даних за порталь-

\section{СПИСОК ЛІТЕРАТУРИ}

1. Химич С. Д. Анализ неудовлетворительных результатов лапароскопической холецистэктомии у пациентов с циррозом печени / С. Д. Химич, Ф. Т. Муравьев, Н. Г. Рудковская // Медичні перспективи. - 2018. - Т. ХХІІІ, № 4. - С. 107-111. 2. Puggioni A. A metaanalysis of laparoscopic cholecystectomy in patients with cirrhosis / A. Puggioni, L. L. Wong // J. Am. Coll. Surg. - 2003. - Vol. 197. - P. 921-926.

3. Laparoscopic cholecystectomy and cirrhosis: patient selection and technical considerations / Rafael S. Pinheiro, Daniel R.

\section{REFERENCES}

1. Khimich, S.D., Muraviov, F.T., \& Rudkovskaya, N.G. (2018). Analiz neudovletvoritelnykh rezultatov laparoscopicheskoy kholetsystektimii u patsitentov s tsirrozom pecheni [Analysis of unsatisfactory results of laparoscopic cholecystectomy in patients with cirrhosis]. Medychni perspektyvy - Medical Prospects, XXIII (4), 107-111.

2. Puggioni, A., \& Wong, L.L. (2003). A metaanalysis of laparoscopic cholecystectomy in patients with cirrhosis. J. Am. Coll. Surg., 197, 921-926.

3. Rafael, S., Pinheiro, Daniel R. Waisberg, Quirino Lai, Wellington Andraus, Lucas S. Nacif, Vinicius Rocha-Santos, Luiz, ну гіпертензію; серед них - це індекс deRitis та FibroTest.

Перспективи подальших досліджень. Наша робота, насамперед, дає можливість загострити увагу клініцистів на тому, що цироз печінки (особливо на ранніх стадіях) не завжди може вчасно бути діагностований і може залишитись поза увагою лікарів. Незважаючи на те, що на сьогодні $є$ потужні лабораторні, інструментальні та апаратні методи діагностики, все ж діагностична програма цирозу печінки потребує удосконалення. Це підтверджує і наш випадок, коли у хворого був діагностований деструктивний холецистит, тяжкий цукровий діабет, пієлонефрит, але до лапароскопії не був встановлений цироз печінки.

Waisberg, Quirino Lai [et al.] // Ann. Laparosc. Endosc. Surg. 2017. - Vol. 2. - P. 35

4. Perioperative risk assessment and management of cirrhotic patients / A. L. Simmelink, R. Dong, V. Nayi [et al.] // Journal Hepatol. Gastoint. Dis. - 2015. - Vol 1, Issue 1.

5. Magnetic resonance cholangiopancreatography: utilization and usefulness in suspected choledocholithiasis / J. T. Toppi, M. A. Johnson, P. Page, A. Fox // ANZ J. Surg. - 2014. doi:10.1111/ ans.12867

\& D’Albuquerque, A.C. (2017). Laparoscopic cholecystectomy and cirrhosis: patient selection and technical considerations. Ann. Laparosc. Endosc. Surg., 2, 35

4. Simmelink, A.L., Dong, R., Nayi, V., Ryan, M., \& Johnson, D.A. (2015). Perioperative risk assessment and management of cirrhotic patients. Journal Hepatol. Gastoint. Dis., 1 (1).

5. Toppi, J.T., Johnson, M.A., Page, P., \& Fox, A. (2014). Magnetic resonance cholangiopancreatography: utilization and usefulness in suspected choledocholithiasis. ANZ. J. Surg. doi:10.1111/ans.12867 


\title{
DIFFICULTIES IN PREOPERATIVE MANAGEMENT OF PATIENTS WITH COMPLICATED GALLSTONE DISEASE ON THE BACKGROUND OF LIVER CIRRHOSIS
}

\begin{abstract}
The aim of the work: to determine the main causes of the complexity of the organization of the preoperative period and the diagnosis of liver cirrhosis before surgery.

Materials and Methods. In retrospect, 77 patient histories were analyzed. The criteria for selecting patients for this study were the presence of complicated forms of gallstone disease (acute calculous cholecystitis, choledocholithiasis with obstructive jaundice, Mirizzi syndrome) and the presence of cirrhosis. Depending on the period of diagnosis of cirrhosis, all patients were conventionally divided into 2 groups: group 1 - patients with diagnosed liver cirrhosis of the preoperative stage (62), and group 2 - patients whose cirrhosis was verified intraoperatively (15). All patients in the preoperative period were examined according to the diagnostic protocols for the treatment of patients with complicated forms of cholelithiasis. The stage of cirrhosis was evaluated using the Child-TurcottePugh system and the MELD scale. Among concomitant pathologies, prevailing chronic ischemic mesenteric disease prevailed (group 1 -41 , group $2-4$ ), hypertension (group $1-15$ group $2-2$ ), diabetes mellitus (group $1-1$ and group $2-3$ ), obesity (group $1-2$ and group $2-4)$.

Results and Discussion. According to the results of the study in group 2, a greater percentage of postoperative complications was observed, directly associated with intraoperative diagnosis of liver cirrhosis and the lack of a thorough assessment of the risks of the operation. Diagnosis of cirrhosis of the liver at the preoperative stage in many cases allows a more adequate assessment of the risks of surgical interventions, and appropriate therapy has been previously prescribed significantly reduces the risk of postoperative complications. The most "dangerous" from the point of view of not diagnosing liver cirrhosis at the preoperative stage is the combination of liver cirrhosis with obesity, diabetes mellitus and the presence of postoperative adhesions in the abdominal cavity. In the preoperative period, more attention should be paid to non-invasive diagnostic methods that can help suspect liver cirrhosis, even in the absence of data on portal hypertension; among them is the deRitis and FibroTest index.
\end{abstract}

Key words: gallstone disease; liver cirrhosis.

\section{С. Д. ХИМИЧ, Ф. Т. МУРАВЬЕВ}

Винницкий национальный медицинский университет имени Н. И. Пирогова

\section{С.ЛОНОСТИ ОРГАНИЗАЦИИ ДООПЕРАЦИОННОГО ПЕРИОДА ПРИ ЛЕЧЕНИИ ПАЦИЕНТОВ С ОС.ОЖНЕННЫМИ ФОРМАМИ ЖЕЛЧНОКАМЕННОЙ БОЛЕЗНИ С СОПУТСТВУЮЩИМ ЦИРРОЗОМ ПЕЧЕНИ}

Цель работы: определение основных причин сложности организации дооперационного периода и диагностики цирроза печени перед проведением операции.

Материалы и методы. Ретроспективно были проанализированы 77 историй болезни пациентов. Критериями отбора пациентов для данного исследования были наличие осложненных форм желчнокаменной болезни (острый калькулёзный холецистит, холедохолитиаз с обтурационной желтухой, синдром Мириззи) и наличие цирроза печени. В зависимости от срока диагностики цирроза все пациенты условно были разделены на 2 группы: группа 1 - пациенты с диагностированным циррозом печени на дооперационном этапе (62), и группа 2 - пациенты, у которых цирроз был верифицирован интраоперационно (15). Все пациенты на дооперационном периоде были обследованы согласно протоколов диагностики лечения больных с осложненными формами ЖКБ. Стадию цирроза оценивали по системе Child-Turcotte-Pugh и по шкале MELD. Среди сопутствующей патологии превалировали хроническая ишемическая болезнь средца (группа $1-41$, группа 2 - 4), гипертоническая болезнь (группа 1 - 15 группа 2 - 2), сахарый диабет (группа 1 - 1 и группа 2 - 3 ), ожирение (группа 1 - 2 и группа 2 - 4).

Результаты исследований и их обсуждения. По результатам исследования в группе 2 наблюдали больший процент послеоперационных осложнений, что непосредственно и связано с интраоперационной диагностикой цирроза печени и отсутствием тщательной оценки рисков выполнения операции. Диагностика цирроза печени на предоперационном этапе во многих случаях позволяет более адекватно оценивать риски проведения оперативных вмешательств, а предварительно назначенная соответствующая терапия значительно снижает риск возникновения послеоперационных осложнений. Наиболее “опасными” с точки зрения недиагностирования цирроза печени на дооперационном этапе является сочетание цирроза печени с ожирением, сахарным диабетом и наличие послеоперационных спаек в брюшной полости. В предоперационном периоде следует больше внимания уделять неинвазивным методам диагностики, которые могут помочь заподозрить цирроз печени, даже при отсутствии данных о портальной гипертензии; среди них это индекс deRitis и FibroTest.

Ключевые слова: желчнокаменная болезнь; цирроз печени. 